\title{
THE IMPORTANCE OF THE PARADIGM SHIFT IN THE DEVELOPMENT OF DESIGN INDUSTRY AND DESIGN EDUCATION
}

\author{
Andra Irbite \\ Faculty of Education, Psychology and Art \\ University of Latvia
}

\begin{abstract}
Literature about design development and the current situation of the essence of trends in this field allow for the defining of design as an independent branch. Analysis of design and education regulations highlights the conflict between reality and gaps that exist in European statistical standards and International Standard Classification of Education. The purpose of this study is to explore complex problems in the field of design and design education_which determines the need for Paradigm Shift for further development of these branches, as well as to present proposals for definitions of key terms of design and offer proposals for a new design education classification. This research will show why, and will mark how design needs to be classified individually, and not as a part of visual arts.
\end{abstract}

Keywords: design, design thinking, visual art, classification, education, Latvia

\section{Introduction}

Design today is identified as one of the key elements of innovation and strategic planning in many countries, including European Union. Design, as a strategic way to ensure the well being of society in the future, is one of Europe 2020's flagship initiatives. In order to use the full potential of design innovation and strengthen the ties between creativity, innovation, entrepreneurship and the public and private sector, the European Commission has initiated a European Design Initiative (European Commission, 2010). The goals of this initiative are to promote understanding of the role of design as an engine for innovation in Europe and to strengthen the role of design in creative ideas and their transfer into the market through creation of user-friendly products, processes or services that facilitate the accessibility of services in Europe.

Thanks to multidisciplinary design, it can be viewed as a part of or unifying element between various branches of economy "to trigger spill-overs in other industries" (European Commission, 2012) - independent economy, creative and scientific activities. Design is generally associated with all branches of the economy, and all branches could have connections with professions associated with design, it suggests that the ability to integrate various competencies in the design process: technological competence, personnel and risk management skills, strategic thinking, creativity, communication skills and the ability to cooperate with other specialists and organizations, as well as openness to international and intercultural cooperation is taking on greater importance.

From the designer's point of view, it seems absurd in this context to prove that the design is_not a trend of art, however, analysis of theoretical and design 
literature, as well as current regulations, reveals a dichotomy between reality and the legacy of the past. The need to find the basis of this perception is clearly indicated in the European Framework for Cultural Statistics (Bina, et al., 2012) in which design is still classified in the Visual Art category, and the International Standard Classification of Education (ISCED), incorporating several organizations that are part of the European Statistical System, in which design is still classified as visual arts education.

Is there an objective need to consider design as a visual art to continue and if so, what are the consequences?

According to previous studies, the lack of data is a challenge to prove the investment of the design industry in the economy. Problems have been identified also in the development of design education. It seems that the design is invisible in statistical systems (European Design Leadership Board, 2012; Design Commission, 2011), as well as an interdisciplinary design program are invisible in the ISCED classifier.

The purpose of this study is to explore complex problems in the field of design and design education_which determines the need for Paradigm Shift for further development of these branches, as well as to present proposals for definitions of key terms of design and offer proposals for a new design education classification

\section{Methodology}

1. Analysis of theoretical literature, associated design literature and documents was carried out in order to clarify the definitions of concepts and explanations of terms related to design using content analysis methods.

2. Theoretical literature was analyzed to prove the necessity for a paradigm shift for the further development of design and design education.

3. Definitions and explanations of design and design thinking are offered for discussion.

Data analysis in the second and third parts of study included grounded theory methods (Cropley, 2002; Glaser, 2002; Bryman and Burgess, 1994) (Table 1).

4. Positive examples, as well as possible solutions in design education were identified and marked in UNESCO documents about associated design education in the fourth and fifth parts of the research. 
Data coding

\begin{tabular}{|c|c|c|}
\hline Categories & Selective Coding & Theoretical coding \\
\hline \multirow[t]{2}{*}{$\begin{array}{l}\text { Design: } \\
\text { Definitions }\end{array}$} & $\begin{array}{l}\text { Artefact: System, Restrictions } \\
\text { Conditions, Usability, Creativity, } \\
\text { Innovation }\end{array}$ & $\begin{array}{llr}\text { Technical and } & \text { ergonomic } \\
\text { parameters of an object, } \\
\text { aesthetics }\end{array}$ \\
\hline & $\begin{array}{l}\text { Process, Strategy: Restrictions, } \\
\text { Conditions, Innovation, } \\
\text { Systems, Creativity }\end{array}$ & $\begin{array}{l}\text { Creation of a product or service: } \\
\text { problem solving, design thinking, } \\
\text { systemic thinking, } \\
\text { people-centred approach, ethics, } \\
\text { imagination, intuition } \\
\text { Intangible }\end{array}$ \\
\hline $\begin{array}{l}\text { Art, Design: } \\
\text { Statistical Systems } \\
\text { (ESS net - culture) }\end{array}$ & Thematic structure & Design $-\mathrm{a}$ trend in art \\
\hline $\begin{array}{l}\text { Art, Design: } \\
\text { education (ICSED) }\end{array}$ & $\begin{array}{l}\text { Fields of education and training } \\
\text { Education programs }\end{array}$ & Design as visual art education \\
\hline Design practice & $\begin{array}{l}\text { Co-design } \\
\text { Third Generation design }\end{array}$ & $\begin{array}{l}\text { Design process } \\
\text { Co-creation } \\
\text { Designer } \\
\text { Stakeholder }\end{array}$ \\
\hline Design education & $\begin{array}{l}\text { Traditional skills } \\
\text { Perspective on problem } \\
\text { identification and solving }\end{array}$ & $\begin{array}{l}\text { Interdisciplinarity } \\
\text { Design science }\end{array}$ \\
\hline Paradigm & Paradigm shift & New mental model \\
\hline
\end{tabular}

\section{Design and Design thinking}

"Although design is often interpreted as art with a reference to common features in the process of creating both art and design work, design is to be considered an independent branch" (Irbite, 2013a, Irbite, 2013b). It has not lost the link with art, but its borders have widened. Design has changed over the centuries to become multi-disciplinary through the merging of individual design fields, as well through the division of basic disciplines into several branches that are connected to new theories, technologies and societal needs. New design fields, such as Service Design, Strategic Design is connected to the immaterial systems, processes, attitudes, experience and relationships.

In this context, design is a 'complex societal activity' (Hardt, 2006) and as the term, designating that activity and its results, has many definitions and explanations. It is used both as a noun that describes the technical parameters of an object and its esthetic form in a concrete setting and as a verb that describes the process of creating a product or service (Commission of European communities, 2009; Design 2020; Vision Committee, 2011; International Council of Societies of Industrial Design, Dancing Water, 2009).

Today design is also defined as a strategy (European Design Leadership Board, 
2012; Brown, 2005; Guellerin, 2001) for reaching a goal that is defined by the project's parameters and processes, as a driver for people-centred innovation (Commission of European communities, 2009; Myerson, 2009; Design Leadership Board, 2012) and as an integrated approach to complicated and poorly-formed problem solving (Rittel and Webber, 1973; Visser, 2010; Buchanan, 1992) - a way of thinking or design thinking.

The term 'design thinking' does not have a single, generally accepted definition. Various authors (Brown, 2008; Martin, 2009) offer explanations and interpretations of the term.

As Haasi and Laakslo (2011) concluded in their study, three main accounts are identified: design thinking as a cognitive style, as a general theory of design, and as a resource for organizations.

It follows that extending the boundaries of design branch makes it necessary to expand the concept of the design, but it is important from time to time define and explain more precisely the basic concepts and terms. This is particularly important in design education.

\section{Paradigms, design and design education}

Many countries have developed national design policies, strategies and visions (Design Council, 2012; DesignSingapore Council et al., 2009; The Danish Government, 2007) to encourage excellence in design as the main factor of competitiveness. One of the goals in any design strategy is the supplementation of that branch of education.

Despite the wide possibilities of design industry, problems are identified also in design education. As indicated in the reseach „Mapping of International Design Policies and Strategies for leading design schools and research institutions" (Quartz+Co at al, 2011), most of design schools in this analysis are focusing on traditional design disciplines, such as industrial design, fashion, advertising, interior design, etc. Such a situation can be observed also in Latvian design education. Although design education has become more interdisciplinary "...it is mature the need for a new kind of designers, one that has traditional skills and yet a much broader perspective on problem identification and solving" (Quartz+Co et al., 2011).

Where is the problem? On the one hand, the design industry has reached a new level of maturity and the need for a new type of designers to implement national industrial policies, and the design objectives have been established. On the other hand, design is invisible in statistical systems, is classified as a form of art and design education is developing slowly. These facts indicate that the problem is not only the lack of social understanding which is often limited by stereotypes and personal experience. The establishment of both statistical and educational system is a collective work, in which relevant industry professionals with a corresponding education have been involved. Today developing autonomous 
fields of science and professional practice are promoting the accumulation of knowledge and thus forming more and more new values and facts. However, it facilitates the fragmentation of knowledge. The number of branches has increased and they have lost the connection between them, resulting in common problems.

According to Mathijs and Mosselmans (1999), human intellectual activity begins an investigation of the object, which is embedded in specific institutions and tied together with a leading "paradigm.

Khun defined a paradigm as universally recognized scientific achievements that, for a time, provide model problems and solutions for a community of practitioners (Kuhn, 1962 a). In a "normal science" (Khun, 1962 a) research is firmly "based upon one or more past scientific achievements, achievements that some particular scientific community acknowledges for a time as supplying the foundation for its further practice" (Kuhn, 1962a). In other words, paradigms are self-sustaining cultures or belief systems and are interconnected with the other major paradigms (Metadesigners Open Network, 2013).

And in this regard, it is the paradigm of design as the part of visual arts that creates a series of consequential problems: determining the impact of design on economy (European Design Leadership Board, 2012; Design Commission, 2011), as well as in the development of design education. This paradigm may be due to the paradigm of Liberal arts.

Non-compliance with the existing paradigm or 'anomaly' "appears only against the background provided by the paradigm. The more precise and far-reaching that paradigm is, the more sensitive an indicator it provides of anomaly and hence of an occasion for paradigm change" (Kuhn, 1962b).

History of science suggests that from time to time paradigms or collective mental models are barriers for development. Paradigm shift is nothing more than a change from one way of thinking or conceptual framework to another. Designers are referred to as agents of change because the strategic importance of design is not only to solve problems but also to identify them. Design paradigms are no longer relevant only to design solutions or design problem solving in the traditional fields of design. Design thinking, which should become more systemic, makes a paradigm shift possible.

I believe that the paradigm shift from design as a trend in art to design as an independent branch and field of science will not only establish its status de facto, but also will contribute to the growth of design industry and the development of design education.

However, as recognized by Mathijs and Mosselmans (1999), the problem can be stated as follows: a discussion within an institution is not fruitful, since the role of creativity diminishes. „Discussion without any form of institution is impossible, since everyone stays on his postmodern island. We should dissolve the boundaries between institution and discussion. The discussion itself should be the institution" (Mathijs and Mosselmans, 1999). 


\section{Discussion}

Definitions of basic terms

1. It is important to formulate what design is today, not only for individual areas of design or in strategy document development, but in the context of the real activities and needs in the context of the whole industry, in particular, for design education. There are different opinions on what 'third generation design' is from perspective of systems thinking, from which it follows that stakeholders are designers (Pourdehnad et al; Goetzke, 2010; Jackson, 2003).

The author of this article believes that the design community, regardless of the field in design, should stick to common understanding about the meaning and usage of these terms: what is design; and who is designer - anyone who tries to change something for the better or, however, a person with appropriate design education?

I agree with Wand (2009) that clear definitions of key terms can help the development of a cumulative body of research and support the analysis of empirical results and integration of theories.

2. Design thinking has become a paradigm that is considered to be useful in solving many problems, especially, in business and strategic management. However, the expansion of understanding of design thinking is important also for designers, design theorists and researchers, as well as in the design of the educational process and content creation. As Kimbell (2011) notes, "Design thinking does, however, remain undertheorized and understudied; indeed, the critical rethinking of design thinking has only just begun".

\section{The role of Paradigm shift in Design education}

As has been proven in previous studies, design is not a trend of art, so design education is not the same as art of education. However, analysis of the International Standard Classification of Education (UNESCO Institute for Statistics, 2013) and the Standard Classification of Education: Fields of Education and Training 2013 indicate that design education is classified as art education. Design includes Broad field 02 Arts and humanities, Narrow field 021 Arts and Detailed fields: 0211 Audio-visual techniques and media production; 0212 Fashion, interior and industrial design; 0213 Fine arts; 0214 Handicrafts; 0215 Music and performing arts; and 0218 Inter-disciplinary programs and qualifications involving arts.

This leads to the question whether "art" should be understood as a liberal art and should design education be classified as a liberal arts education? Today, design schools around the world offer interdisciplinary study programs, such as Business Design (Domus Academy), Strategic Product Design (Delft University of Technology), Strategic Design (Brunel University) and Design Management (Aalto University) that cannot be attributed to the visual arts. Even if design schools offer art as a part of their traditional design course, such as Industrial Design, Graphic Design and Interior Design, they are 
interdisciplinary, nevertheless. Professional competencies in the design field may fulfill requirements for programs that are formulated as 'Inter-disciplinary programs and qualifications', but design education cannot be grounded on the acquisition of visual arts courses.

\section{Results}

Design, designer, co- design and design thinking: definitions and explanations Based on the analysis of theoretical literature, associated design literature and documents which was carried out to summarize concepts of basic of terms related to the design, the author of the article offers her definitions and explanations for discussion.

1. Design. With regard to evolution of the design and its wide application possibilities in different sectors of the economy, I offer the following definition of design.

Design is a professional and creative activity which is based on the aesthetic and/or ethical values and includes tangible and intangible values. It involves planning and developing of objects, processes and systems in a particular environment, which is based on economic, technological, physical, psychological, social, cultural, political and environmental factor research and their final outcome (Irbite, 2013c).

2. Designer. It follows that designer is a person with an appropriate design education and qualifications.

3. Co-design. In the process of working with stakeholders and professionals from other fields, it is necessary to develop a shared mental model (Jones et al, 2011; Ozesmi et al., 2004; Morgan et al., 2002; Langan-Fox et al., 2001) to provide a mechanism by which new information is filtered, stored and used to reach common goals. It is not the same as design process. It is the process of cocreation, definition of project development criteria or the research process where appropriate methods are used to define them. In this process a designer is the designer, a PR professional is the PR professional, a user is the stakeholder, a manager is the manager and so on. It is not co-design, but co-work or cocreation.

Hassi and Laakso (2011) conclude: "The concept of design thinking as described in literature is not something that can be learned "from the books" or from abstract representations, but rather requires practicing it".

I believe that stakeholders could be considered as design thinkers.

4. Design thinking. Any of the of design fields is associated with several economic sectors and areas of science. Therefore I define Design Thinking as an analytical, critical, systemic and innovative approach to individual and society problem solving, where scientific methods and tools are used. Innovation in this context must be understood as a deliberate application of information, imagination and intuition to create positive changes taking account of the 
constraints.

Design thinking is an integral part of design or a strategic process. Final outcome is a process quality indicator.

\section{ISCED and Design education}

It is difficult to incorporate design education in one of the Broad fields categories by tying it to a defined branch or economic activity. A possible solution may be to add the term 'Design' to 'Arts and Humanities'. In this case, it would be possible to incorporate design specialties into the Detailed Field. However, design is not affiliated with the humanities alone.

ISCED defines an education program as a coherent set or sequence of educational activities or communication designed and organized to achieve predetermined learning objectives or accomplish a specific set of educational tasks over a sustained period (UNESCO Institute for Statistics, 2011). Therefore, if a design program is considered to be a baseline to ensure desired long-term outcomes, the time has come to adjust thematic branch classifications to current reality.

By creating a new Broad field Design category, it would be possible to include both professional and academic education programs in the Narrow field.

According to Stolterman, "Design research conducted according to strict scientific procedures can produce highly valuable knowledge for practicing designers" (Stolterman, 2008). The term 'Design Science' (Fuller, 1992; Friedman, 2006; Ben-Eli, 2007; Holinen, 2012) used today, characterizes all aspects of modern design as a scientific activity, as a body of knowledge that includes knowledge of natural and artificial systems, knowledge and methods to create the artificial objects and systems and to design research.

\section{Latvian experience}

Latvia is a relative newcomer to the design arena, even though the country has stable design school traditions that are nurtured and improved. In the development of the design strategy Radoša Latvija [Creative Latvia] were included representatives of the Latvian Cultural Alliance, Latvian Designer Association (LDS), Ministries of Culture and Economics, Chambers of Commerce and Trade and institutes of higher education. A new trend is the LDS work group's initiative to make changes in Latvian education and ISCED classifiers. LDS' strategic partners are administrators of and teachers at professional schools and higher education design programs, who support this initiative. Other foreign partners - designers and university representatives have also expressed positive feedback about this initiative.

The LDS plan to continue to cooperate with other European professional associations, university representatives, researchers and designer, requesting 
them to express their opinions and mutually find solutions to the questions: Is design in the $21^{\text {st }}$ century a visual art, or has the time come to view design as design?

\section{Conclusions}

1. Discussion among design professionals and design thinkers about the use of key terms would be necessary in the future.

2. The paradigm shift from design as a part of visual arts to design as an independent field is necessary for further development of the industry.

3. The admonition that design is classified as a visual art, as reflected in EU and UNESCO documents and classification systems, is out of date.

4. It is necessary to make changes in statistical systems, such as ESSnet culture, as well as in ISCED classification for fields of education and training, by identifying design as a separate category for three reasons:

i. it could change the public's understanding of the role of design in the economic processes;

ii. competitive design can created by a competitive designer; the changes in education classifiers could promote design education and research, as well as a more responsible attitude to curriculum development in educational institutions and more serious personal attitudes of students towards their career building;

iii. these complex activities could contribute to qualitative growth of the design industry.

5. As Latvia's example shows, cooperation between professional creative organizations, cultural and state institutions, as well as business and higher education institutions can encourage and help initiate the positioning of design as an independent field in the education system.

\section{References}

1. Ben-Eli, M. (2007). Design Science: A Framework for Change, available at: http://www.u.arizona.edu/ shunter/Design_Science_Framework.pdf

(accessed: 17.02.2014)

2. Bina, V., Chantepie, P., Deroin V., Frank, G., Kommel, K., Kotynek, J., Robines, J. (2012). European Statistical System Network on Culture, Final Report, pp.43- 44, 55, available at: http://ec.europa.eu/culture/our-policy-development/documents/ess-netreport-oct2012.pdf (accessed: 17.02.2014)

3. Brown, T. (2008). Definitions of design thinking, available at: http://designthinking. ideo.com/?p=49 (accessed: 17.02.2014)

4. Brown, T. (2005). Strategy by Design, available at: http://www.fastcompany.com/ (accessed: 17.02.2014)

5. Buchanan, R. (1992). Wicked Problems in Design Thinking, Design Issues, Volume 8, No. 2, pp. 5-21, available at: http://www.jstor.org/discover/10.2307/1511637?uid= 

17.02.2014)

6. Bryman, A. and Burgess, R.G. (1994). Developments in qualitative data analysis: an introduction", in Bryman, A. and Burgess, R.G. (Eds.), Analyzing qualitative data, Routledge, Abingdon, UK, pp. 3-6

7. Commission of European communities (2009). Design as a driver of user-centred innovation, pp.9,58, available at: http://ec.europa.eu/enterprise/policies/ innovation/files/design_swd_sec501_en.pdf (accessed: 17.02.2014)

8. Cropley, A. (2002). Qualitative research methods. Riga, Zinātne.

9. Dancing Water (2009). 27 design definitions, available at: http://dancingwater.eu/ 2009/27-design-definitions/ (accessed: 17.02.2014)

10. Design Commission (2011). Restarting Britain: Design Education and Growth, pp. 4849, available at: http://designmuseum.org/media/item/79241/4288/Design-CommissionRestarting-Britain-Design-Education-and-Growth.pdf (accessed: 17.02.2014)

11. Design Council (2008). Measuring return on investment in design (ROI), available at: $\mathrm{http}$ //www.designcouncil.org.uk/our-work/Insight/Research/How-businesses-usedesign/Design-in-Britain-2008/Measuring-ROI-in-design/ (accessed: 17.02.2014)

12. Design 2020 Vision Commitee (2011). The Vision of the Design2020 Commitee, pp.11, available at: www.beda.org/index.php/resources/item/download/29 (accessed: 17.02.2014)

13. Design Singapore Council, Ministry of Information, Communications and Arts (2009). Strategic Blueprint of the Design Singapore initiative, available at: $\mathrm{http}: / /$ www.mci.gov.sg/content/dam/mica_corp/Publications/MasterPlan/Download/Down load1/ERCdesignsingapore.pdf (accessed: 17.02.2014)

14. European Commission (6.10.2010). Europe 2020 Flagship Initiative. Innovations Union, pp. 19, available at: http://eur-lex.europa.eu/LexUriServ/LexUriServ.do?uri= COM:2010:0546:FIN:EN:PDF (accessed: 17.02.2014)

15. European Design Leadership Board (2012). Design for growth and prosperity, pp.38;41, available at: http://ec.europa.eu/enterprise/policies/innovation/policy/design-creativity/ (accessed: 17.02.2014)

16. European Commission (26.9.2012). Promoting cultural and creative sectors for growth and jobs in the EU, pp.7, available at: http://ec.europa.eu/culture/our-policydevelopment/documents/communication-sept2012.pdf (accessed: 17.02.2014)

17. Fuller R.B. (1963). Ideas and Integrities, The Macmillan Company; First Collier Edition.

18. Glaser, B.G. (2002). Constructivist Grounded Theory?, Forum: Qualitative Social Research, vol.3, No.3, Art.12, available at: http://www.qualitativeresearch.net/index.php/fqs/article/view/825/1793 (accessed: 17.02.2014)

19. Goetzke, A. (2010). Creative Industries Convention 2010 Interview, available at: http://www.vimeo.com/9402566 (accessed: 17.02.2014)

20. Hardt, M. (2006). Design the term design, available at: http://www.michaelhardt.com/PDF/lectures/design-definition.pdf (accessed: 17.02.2014)

21. Hassi, L., Laakso, M. (2011). Design Thinking in the Management discourse; defining the elements of the concept, available at: http://www.mindspace.fi/wpcontent/uploads/2013/12/HassiLaakso_2011_IPDMC.pdf (accessed: 17.02.2014)

22. Halinen, R, (2012). Information Systems Action design research method, available at: http://www.slideshare.net/RaimoHlinen/information-systems-research-method (accessed: 17.02.2014)

23. Irbite, A. (2013a). Traditions and innovations in Latvian design education, The $1^{\text {st }}$ International Virtual Conference on Advanced Scientific Results, Proceedings in Scientific Conference, ISBN 978-80-554- 0726-5, pp. 230-236 
24. Irbite, A. (2013b) The Evolution of Design during 20th-21st centuries, Art Tempus, Volume 1, pp. 16-28

25. Irbite, A. (2013c). Ministry of Culture of the Republic of Latvia, Creative Latvia, Design Strategy, Preamble (working paper)

26. Jackson, M.C. (2003). Systems thinking: Creative holism for managers. University of Hull, UK: John Wiley \& Sons, available at: http://orgcomplexitynet.groupsite.com/ uploads/files/x/000/02f/e18/Systems_Thinking_-_Creative_Holism_for_Managers.pdf (accessed: 17.02.2014)

27. Jones, N. A., Ross, H., Lynam T., Perez, P., Leitch, A. (2011). Mental models: an interdisciplinary synthesis of theory and methods. Ecology and Society 16 (1), pp. 46, available at: http://www.ecologyandsociety.org/vol16/iss1/art46/ (accessed: 17.02.2014)

28. Kimbell, L.(2011). Rethinking Design Thinking: Part I, Design and Culture, Volume 3, Issue 3, pp.285-306, available at: http://www.designstudiesforum.org/dsf/wpcontent/uploads/2011/11/kimbell_wm.pdf (accessed: 17.02.2014)

29. Kuhn, T.S. (1962a). The Structure of Scientific Revolutions, 3rd edition, University of Chicago Press.

30. Kuhn, T.S. (1962b), The Structure of Scientific Revolutions, 3rd edition, University of Chicago Press.

31. Langan-Fox, J., Wirth, A., Code, S. Langfield-Smith, K., A. Wirth, A. (2001). Analyzing shared and team mental models. International Journal of Industrial Ergonomics, Volume 28, pp.99-112

32. Martin, R. (2009). Design Thinking: How Thinking Like a Designer Can Create Sustainable Advantage, Harward Business Publishing, available at: http://hbsp.harvard.edu/ (accessed: 17.02.2014), available at: https://intranet.ebc.edu.mx/ contenido/faculty/archivos/pensamiento_diseno_221111.pdf (accessed: 17.02.2014)

33. Mathijs, E., Mosselmans, B. (1999). Similarity or Difference: The Case for Interdisciplinarity between Natural Sciences, Social Sciences and Art and Aesthetics, Interdisciplinarity: Documents, available at: http://pegasus.cc.ucf.edu/ janzb/ humanities/intdoc.htm (accessed: 17.02.2014)

34. Meta designers Open Network (2013).Working to Change the Paradigm, available at: $\mathrm{http}: / /$ metadesigners.org/Paradigm-Changing (accessed: 17.02.2014)

35. Morgan, M. G., Fischhoff, B. Bostrom, A., Atman, J C. (2002). Risk communication: a mental models approach. Cambridge University Press, New York, ISBN 0-521-80223-7, pp. 22-31

36. Myerson, J. (2009). The Future Of Innovation Will Be People-centred, available at: http://thefutureofinnovation.org/contributions/view/681/the_future_of_innovation_will_b e_people_centred (accessed: 17.02.2014)

37. Ozesmi, U., Ozesmi S.L. (2004). Ecological models based on people's knowledge: a multi-step fuzzy cognition mapping approach. Ecological Modeling, Volume 176, pp.4364

38. Rittel, H., Webber M. (1973). Dilemmas in a General Theory of Planning, Policy Sciences 4(1973), pp.160-163, available at: http://www.metu.edu.tr/ baykan/ arch467/Rittel\%2BWebber\%2BDilemmas.pdf (accessed: 17.02.2014)

39. Ritchie, J., Spencer, L. (1994). Qualitative data analysis for applied policy research, in

40. Rittel, H.W., Webber, M.M. (1973). Dilemmas in a General Theory of Planning, Policy Sciences, Vol. 4, Elsevier, pp. 155-169, available at:

http://www.uctc.net/mwebber/Rittel+Webber+Dilemmas+General_Theory_of_Planning. pdf (accessed: 17.02.2014)

41. The Danish Government (2007). Design Denmark, available at: http://www.beda.org/index.php/resources/item/download/ (accessed: 17.02.2014) 
42. UNESCO Institute for Statistics (2013). Revision of the International Standart Classification of Education: Fields of Education and Training (ISCED-F), pp.7,73, available at: http://www.uis.unesco.org/Education/Documents/isced-37c-fos-review222729e.pdf (accessed: 17.02.2014)

43. UNESCO Institute for Statistics (2011). International Standard Classification of Education, pp.7, available at: http://www.uis.unesco.org/Education/Documents/isced2011-en.pdf (accessed: 17.02.2014)

44. Visser, W. (2010). Simon: Design as a problem-solving activity, available at: http://hal.archives-ouvertes.fr/docs/00/56/58/86/PDF/SimonDesignAsAProblemSolving. pdf (accessed: 17.02.2014)

45. Wand, Y. (2009). A Proposal for a Formal Definition of the Design Concept, Position Paper, available at: http://weatherhead.case.edu/events/requirements/Wand_DRW.pdf (accessed: 17.02.2014)

46. Quartz \& Co; the Danish Enterprise and Construction Authority; the Danish Ministry of Culture ( 2011). Mapping of International Design Policies and Strategies for leading design schools and research institutions, pp.23, available at: http://erhvervsstyrelsen.dk/file/163743/mapping_international_design_policies_strategies .pdf (accessed: 17.02.2014)

Andra Irbīte
Latvijas Universitāte, Pedagoǵijas, psihologiijas un mākslas
fakultāte
Jūrmalas gatve 74/76, Rīga, LV- 1083
e-pasts: andra.irbite@lu.lv
tel. :+37129455920

